\title{
HAPTOGLOBIN POLYMORPHISM IN THE MIDDLE EAST
}

\author{
Dariush D. FARHUD \\ Unit of Human Genetics and Anthropology, Department of Hunan Ecology, \\ School of Public Health, University of Tehran, \\ P.O. Box 1310, Tehran, Iran
}

\begin{abstract}
Summary The distribution of haptoglobin types in Iranians $(\mathrm{n}=627)$ is reported. $H p^{1}$ gene frequencies, collected from published material, among Middle East populations are given. The interpretations of noted observations are discussed.
\end{abstract}

\section{INTRODUCTION}

Most human populations have been shown to be polymorphic for a number of blood groups, serum proteins and red cell enzymes. Smithies (1955) demonstrated that when human serum is subjected to electrophoresis, haptoglobin differentiates into three patterns which are found in most populations. Later, family studies carried out by Smithies and Walker (1956) suggested that these groups are controlled by two autosomal alleles, $H p^{1}$ and $H p^{2}$, without dominance.

Data on geographic distribution of haptoglobin phenotypes in different populations of the world have been accumulated (Giblett, 1969; Kirk, 1968; Sutton et al., 1959). Such studies have shown marked differences in the frequencies of $H p^{1}$ and $H p^{2}$ genes among European, African and Asian populations.

Knowledge on the distribution of polymorphic systems in the Middle East is rather limited and extensive data are only available regarding the ABO system. The present survey was carried out to enlarge our knowledge of the distribution of haptoglobin types in Iran and to contribute to the better understanding of genetic polymorphism in the Middle East.

\section{MATERIALS AND METHODS}

Blood samples, obtained from Iranians, were collected in $5 \mathrm{ml}$ tubes. Serum was separated immediately and stored at $-20^{\circ} \mathrm{C}$ until used. The persons sampled were healthy and unrelated. Horizontal starch gel electrophoresis was carried out

Received February 17, 1980 
Table 1. The distribution of haptoglobin types in Iranians.

\begin{tabular}{ccccc}
\hline Hp phenotype & Obs. No. & Exp. No. & Obs. Freq. & Exp. Freq. \\
\hline $1-1$ & 49 & 49.40 & 0.0781 & 0.0788 \\
$2-1$ & 254 & 253.19 & 0.4051 & 0.4038 \\
$2-2$ & 324 & 324.40 & 0.5167 & 0.5174 \\
$0-0$ & - & - & - & - \\
Total & 627 & 626.99 & 0.9999 & 1.0000 \\
\hline
\end{tabular}

Gene frequencies: $H p^{1}, 0.2807 ; H p^{2}, 0.7193$.

Table 2. Distribution of $H p^{l}$ gene frequencies in the Middle East.

\begin{tabular}{|c|c|c|c|}
\hline Origin & No. tested & $H p^{I}$ frequency & Authors \\
\hline Turkish & 274 & 0.25 & Hummel et al. (1970) \\
\hline Kuwaitis & 158 & 0.345 & Sawhney (1975) \\
\hline Iraquis & 118 & 0.288 & Ramot et al. (1961) \\
\hline Iraq (Jews) & 118 & 0.29 & Ramot et al. (1962) \\
\hline Iraq (Jews) & 197 & 0.270 & Fried et al. (1963) \\
\hline Arabs (S. Arabia) & 92 & 0.445 & Marengo-Rowe et al. (1974) \\
\hline Israeli (Arabs) & 75 & 0.36 & Ramot et al. (1962) \\
\hline Israelis (Orientals) & 345 & 0.26 & Goldschmidt et al. (1962) \\
\hline Israeli (Kurds) & 113 & 0.36 & Ramot et al. (1962) \\
\hline Kurdish Jews & 96 & 0.300 & Fried et al. (1963) \\
\hline Israeli (Ashkenazim) & 170 & 0.34 & Ramot et al. (1962) \\
\hline Israeli (Ashkenazim) & 499 & 0.27 & Goldschmidt et al. (1962) \\
\hline Ashkenazi Jews & 699 & 0.300 & Fried et al. (1963) \\
\hline Israel (Iran Jews) & 158 & 0.310 & Simhai (1976) \\
\hline Yemen Jews & 41 & 0.250 & Fried et al. (1963) \\
\hline Haban Jews & 589 & 0.210 & Bonné et al. (1970) \\
\hline Towara Bedouin & 198 & 0.429 & Bonné et al. (1971) \\
\hline Jebelliya Bedouin & 95 & 0.789 & Bonné et al. (1971) \\
\hline Iranians & 627 & 0.281 & Present study \\
\hline Iranians & 360 & 0.270 & Farhud \& Walter (1972) \\
\hline Iranians & 34 & 0.25 & Harris et al. (1959) \\
\hline Iranians & 97 & 0.354 & Walter \& Djahanschahi (1963) \\
\hline Iranians & 1,016 & 0.28 & Miyashita \& Ohkura (1975) \\
\hline Iranians (Caspian Littoral) & 448 & 0.214 & Kirk et al. (1977) \\
\hline Iranians & 1,566 & 0.288 & Bajatzadeh \& Walter (1969) \\
\hline Iranians & 1,020 & 0.305 & Bajatzadeh \& Walter (1968) \\
\hline Iranians & 275 & 0.296 & Sawhney $(1975)$ \\
\hline Iranian Moslems & 429 & 0.28 & Bowman (1964) \\
\hline Iranian Zorastrians & 145 & 0.19 & Bowman (1964) \\
\hline Iranian Ghashquai & 117 & 0.33 & Bowman (1964) \\
\hline Iranian Jews & 91 & 0.30 & Ramot et al. (1962) \\
\hline Iranian Jews & 101 & 0.290 & Fried et al. (1963) \\
\hline Iranian Jews & 459 & 0.320 & Tabatabai (1976) \\
\hline Iranian Armenians & 228 & 0.344 & Tabatabai (1976) \\
\hline
\end{tabular}


using the discontinuous system of Poulik (1957) at $\mathrm{pH}$ 8.6. The haptoglobin patterns were typed by benzidine staining.

\section{RESULTS}

The distribution of $\mathrm{Hp}$ groups and respective gene frequencies were calculated by the gene counting method (Table 1). Close agreement was observed between the expected and phenotypic values, thus confirming the Hardy-Weinberg equilibrium. No Hp 2-1 (modified) or rarer phenotype was detected.

\section{DISCUSSION}

Data on the distribution of $H p^{I}$ gene frequencies in various Middle East populations are set out in Table 2. Studies conducted on European populations show that $H p^{1}$ gene frequency is remarkably similar throughout the continent, ranging from 0.36 to 0.43 (Kirk, 1968). In the Middle East, with few exceptions, the $H p^{1}$ frequency is generally lower than that in Europe and usually lie between 0.25 to 0.36. The three major ethnic groups i.e. Iranians, Jews and Arabs in the Middle East, the differences found with regard to $H p^{1}$ values, are insignificant (Ritter et al., 1975). However, the highest $H p^{l}$ values found in the Middle East are among the Jebelliya Bedouin (0.789), the Arabs of Southern Arabia (0.445) and the Towara Bedouin (0.429) (Bonné et al., 1971; Marengo-Rowe et al., 1974). By contrast the lowest values are observed among the Iranian Zoroastrians $(0.19)$ and the Jews living in Haban (0.21) (Bonné et al., 1970; Marengo-Rowe et al., 1974). All other values exhibited by the populations shown in Table 2, are within the specified Middle East range. However, the Middle East populations on the whole exhibit lower $H p^{1}$ values than those found in Europe and higher than those found in India where values range from 0.037 to 0.370 (Sunderland $e t$ al., 1976). There appears to be a cline of increasing $H p^{I}$ gene frequencies from Europe to India via the Middle East, the precise significance of which, in terms of environmental and genetic causation, cannot at present be gauged.

Acknowledgments I am indebted to Dr. K.S. Sawhney, Unit of Human Genetics and Anthropology, School of Public Health, University of Tehran, for helpful discussions.

The present survey was supported by the School of Public Health and the Institute of Public Health Research, Tehran University, partly by the funds of Ministry of Health and plan organization for project No. 670101 .

\section{REFERENCES}

Bajatzadeh, M., and Walter. H. 1968. Serum protein polymorphism in Iran. Hum. Genet. 6: 40. Bajatzadeh, M., and Walter. H. 1969. Investigations on the distribution of blood and serum groups in Iran. Hum. Biol. $41: 401$. 
Bonné, B., Ashbel, S., Modai, M., Godber, M.J., Mourant, A.E., Tills, D., and Woodhead, B.G. 1970. The Habbahite isolate. I. Genetic markers in the blood. Hum. Hered. 20: 609.

Bonné, B., Godber, M.J., Ashbel, S., and Tills, D. 1971. South Sinai Bedouin. A preliminary report on their inherited blood factors. Am. J. Phys. Anthrop. 34: 397.

Bowman, J.E. 1964. Haptoglobin and transferrin differences in some Iranian populations. $\mathrm{Na}$ ture. $201: 88$.

Farhud, D.D., and Walter, H 1972. Haptoglobin subtypes in Iran. Hum. Hered. 22: 184.

Fried, K., Bloch, N., Sutton, E., Neel, J.V., Bayani-Sioson, P., Ranot, B., and Duvdevani, P. 1963. Haptoglobin and transferrin in genetics of migrant and isolate populations. Pub. by. E. Goldschmidt. Williams and Wilkins, New York.

Giblett, E.R. 1969. Genetic markers in human blood. Blackwell and Scientific Public. Oxford.

Goldschmidt, E., Bayani-Sioson, P., Sutton, H.E., Fried, K., Sandar, A., and Bloch, N. 1962. Haptoglobin frequencies in Jewish community. Ann. Hum. Genet. $26: 39$.

Harris, H., Robson, B., and Siniscalco, M. 1959. Genetics of the plasma protein variants in biochemistry of human genetics. Ciba Foundation Symposium. Churchill, London

Hummel, K., Pulvarer, K.P., Schall, P., and Weidman, V., 1970. Haufigkeit der sichtypen. inden. Erbsystemem Haptoglobin, Gc, saure Erythrocytenphosphatase, Phosphoglucomutase and Adenylatkinase, sowiedem Erbeigenschaften Gm (1), Gm (2) und Inv (1) bei Deutschen (Aus dem Freiberg. B. und bei Turken). Hum. Genet. 8: 330.

Kirk, R.L. 1968. Monographs in human genetics. S. Karger, Basel (Switzerland).

Kirk, R.L., Bronya, K., Blake, N.M., McDermid, E.M., Ala, F., Karimi, M., Nickbin, B., Shabazi, H., and Kmet, J. 1977. Genes and people in the Caspian Littoral: A population genetic study in nothern Iran. Am. J. Phys. Anthrop. 46: 377.

Marengo-Rowe, A.G., Godber, M.G., Kopec, A.C., Mourant, A.E., Tills, D., and Woodhead, B.G. 1974. The inherited blood factors of the inhabitants of Southern Arabia. Ann. Hum. Biol. 1: 311.

Miyashita, T., and Ohkura, K. 1975. Distribution of polymorphic traits in Iran. $J_{p n}$. J. Hum. Genet. 20: 55 .

Poulik, M.D. 1957. Starch gel electrophoresis in a discontinuous system ofbuffers. Nature 180: 267.

Ramot, B., Duvdevani-Zikert, P.G., and Kende, G. 1962. Haptoglobin and transferrin types in Israel. Ann. Hum. Genet. 25: 267.

Ramot, B., Duvdevani-Zikert, P.G., and Tauman, G. 1961. Distribution of haptoglobin types in Israel. Nature 192: 765 .

Ritter, H., Jorgensen, G., and Vogel, F. 1975. Handbook of Humangenetik. George Theme Verlag Stuttgart.

Sawhney, K.S. 1975. Genetic polymorphism in South and South East Asia. Ph. D. Thesis. University of Durham, U.K.

Simhai, B.G. 1976. Haptoglobin polymorphism among the Iranian Jews. 7th Pahlavi Medical Conference. Shiraz.

Smithies, O. 1955. Zone electrophoresis in starch gels: group variation in the serum of normal human adults. Biochem. J. 61: 629.

Smithies, O., and Walker, N.F. 1956. Notation for serum protein groups and the genes controlling their inheritance. Nature 178: 694.

Sunderland, E., Sawhney, K.S., Cartwright, R.A., and Jolly, J.G. 1976. Studies of haptoglobin and transferrin types in four castes of the Panjab. Hum. Hered. 26: 16.

Sutton, H.E., Neel, J.V., Livingstone, F.B., Binson, G., Kundstadler, P., and Trombley, L.E. 1959. The frequencies of haptoglobin types in five populations. Ann. Hum. Genet. 23: 175.

Tabatabai, H. 1976. Genetic studies of Armenians and Jews of Iran. M.S.P.H. dissertation, School of Public Health, University of Tehran.

Walter, H., and Djahanschahi, D. 1963. Zur Haufigkeit der Serumgruppen in Persiens. Homo 14: 70 .

Jpn. J. Human Genet. 